\title{
STUDY OF GROWTH AND PRODUCTIONS OF TILAPIA (Oreochromis niloticus) ON DIFFERENT POPULATION DENSITIES IN MONOCULTURE
}

\author{
F. Sharmin', M.S. Rahman' ${ }^{2}$ M. Shahjahan ${ }^{3}$ and P. Chowdhury4*
}

Received 30 October 2019, Revised 17 December 2019, Accepted 24 December 2019, Published online 31 December 2019

\begin{abstract}
The experiment was conducted to determine the effects of population densities of tilapia (Oreochromis niloticus) on the growth and production of tilapia in monoculture system. Fish population density was 80 fish per decimal under treatment-I, 160 fish per decimal under treatment-II and 320 fish per decimal under treatment-III. In the ponds under three treatments supplementary feed was not used. The average initial length and weight of the fry of tilapia was $4.48 \mathrm{~cm}$ and $0.067 \mathrm{~g}$, respectively. The ponds were fertilized fortnightly with urea and TSP at the rates of $60 \mathrm{~g}$, and $90 \mathrm{~g}$ per decimal, respectively. Mean survival rates of fish under treatment-I, treatment-II and treatment-III were $91.12 \%, 82.82 \%$ and $66.23 \%$, respectively. The specific growth rates (SGR, \% per day) of fish under treatment-I, treatment-II and treatment-III were $5.49 \%, 4.95 \%$ and $4.61 \%$, respectively. The calculated net fish production of the ponds under treatment-I was 2.65 ton $\mathrm{ha}^{-1} \mathrm{yr}^{-1}$ and that of the ponds under treatment-II was 2.55 ton $\mathrm{ha}^{-1} \mathrm{yr}^{-1}$ and that of the ponds under treatment-III was 2.68 ton $\mathrm{ha}^{-1} \mathrm{yr}^{-1}$. The net fish production under treatment-I and treatment-III were 2.65 ton $\mathrm{ha}^{-1} \mathrm{yr}^{-1}$ and 2.68 ton $\mathrm{ha}^{-1} \mathrm{yr}^{-1}$ higher than that of treatment-II, taking net fish production under treatment-I for $100 \%$. According to survival rates and specific growth rates treatmentI is the best. So, the population density of 80 fish per decimal (under treatment-I) might be considered the best among the three treatments.
\end{abstract}

Keywords: Tilapia, Stocking Density, Production, Water Quality.

\footnotetext{
${ }^{1}$ Department of Fisheries Management, Bangladesh Agricultural University, Mymensingh-2202.

${ }^{2}$ Professor, Department of Fisheries Management, Bangladesh Agricultural University, Mymensingh-2202.

${ }^{3}$ Professor, Department of Fisheries Management, Bangladesh Agricultural University, Mymensingh-2202.

${ }^{4}$ Scientific Officer, Bangladesh Fisheries Research Institute, Headquarters, Mymensingh-2201.

*Corresponding author’s email: nitoldhk@ gmail.com (P. Chowdhury)
}

Cite this article as: Sharmin, F., Rahman, M.S., Shahjahan, M. and Chowdhury, P. 2019. Study of growth and productions of tilapia (Oreochromis niloticus) on different population densities in monoculture. Int. J. Agril. Res. Innov. Tech. 9(2): 76-83. DOI: 10.3329/ijarit.v9i2.45414.

\section{Introduction}

Fish and Fisheries play very significant roles in our national economy such as nutrition, income generation, and employment and foreign exchange earnings. The protein problem can be reduced by increasing the fish production through modern and scientific fish culture and management practice. Modern fish culture means improvement of culture practices through adopting different measures such as proper doses of fertilizer application, regular feeding, optimum stocking density, maintenance of the physicochemical factors, prevention of diseases and various control measures. Therefore, to make protein easily available to the people, it is essential to increase the pond fish production in
Bangladesh. However, government and nongovernment organizations have been exerting efforts and allocation of resources for productionoriented research and also initiation and encouraging the rural people to improve pond fish culture techniques and methods (DoF, 2009). For successful aquaculture, knowledge on several factors is very important among which stocking density of different fish species also plays a vital role in the growth of fish. Higher density of species may affect the growth of another species similarly lower density of a species may reduce the overall production. 
Stocking density is the major concern for monoculture. Sometimes excellent fish fry do not perform satisfactorily unless correct stocking practices. In general the stocking density and growth of fish are very much related, the optimum stocking density ensure sustainable aquaculture providing proper utilization of feed, maximum production, sound environment and health. Although individual growth of fish is high, proper utilization of water body is not possible at the low stocking density. In comparison to low stocking density, high stocking density exerts many negative impacts such as competition for food and shelter and rapid out-break of diseases may occur. Therefore, it is important to optimize the stocking density for the target species in aquaculture for desired production. Tilapias are a group of 'Cichlid' fish native to African countries. Now it could be found in more than 100 countries (Ballarin and Haller, 1982). Tilapias have been distributed to so many different types of water, to so many different types of culture systems in the world that they have been even labeled as the "aquatic chicken" (Maclean, 1984). Tilapias are mainly freshwater fish inhabiting shallow streams, ponds, rivers and lakes and less commonly found living in brackish water. Tilapia have been called as the 'everyman's fish" (Pullin, 1985). The introduction of tilapia in Bangladesh from Thailand was first initiated in 1954 with $T$. mossambicus (Ahmed, 1956) and later in 1974, high yielding species of tilapia (O. niloticus) was introduced by UNICEF (Rahman, 1995) with a hope that it would make a significant

\section{Experimental design}

Table 1. The layout of the experiment.

\begin{tabular}{|c|c|c|c|c|c|}
\hline Treatments & Replications & Pond no. & Fish species & $\begin{array}{c}\text { Fish } \\
\text { Population } \\
\text { Density }\end{array}$ & Fertilization \\
\hline $\mathrm{I}$ & $\begin{array}{c}2 \\
\text { (2 ponds) }\end{array}$ & $\mathrm{P}_{1}, \mathrm{P}_{5}$ & $\begin{array}{c}\text { Tilapia } \\
\text { (Oreochromis } \\
\text { niloticus) }\end{array}$ & $\begin{array}{l}80 \text { fish per } \\
\text { decimal }\end{array}$ & \multirow{3}{*}{$\begin{array}{l}\text { Urea } 60 \text { g, } \\
\text { TSP } 90 \text { g per } \\
\text { decimal per } \\
\text { week }\end{array}$} \\
\hline II & -Do- & $\mathrm{P}_{2}, \mathrm{P}_{4}$ & Do & $\begin{array}{l}\text { 16o fish per } \\
\text { decimal }\end{array}$ & \\
\hline III & -Do- & $\mathrm{P}_{3}, \mathrm{P}_{6}$ & Do & $\begin{array}{l}320 \text { fish per } \\
\text { decimal }\end{array}$ & \\
\hline
\end{tabular}

\section{Pond preparation}

\section{Pond drying, dyke repairing and liming}

Before starting the experiment the ponds were dried, aquatic higher vegetations and unwanted aquatic animals were removed manually. Pond dykes were repaired and renovated. Liming $(\mathrm{CaO})$ was done in all the ponds at rate of $1 \mathrm{~kg}$ decimal $^{-1}$ before 7 days of fertilization.

\section{Water supply}

Ponds were supplied with water after 7 days of liming from a deep tube-well water supply system; rainfall was also a source of water supply to the ponds. contribution to fish production but the attempt was not successful because very little efforts were made to understand the culture management by the farmers. Bangladesh Fisheries Research Institute (BFRI) again brought a fresh batch of $O$. niloticus from Thailand in 1987 and developed low input and low cost technologies. Then, such technologies have been transferred to hundreds of farmers throughout the country by government extension workers and NGO's.

The stocking density is the major concern for mono-culture. Sometimes excellent fish fry do not perform satisfactory growth unless correct stocking practices (Sanches and Hayashi, 1999). So, the present experiment has been undertaken to find out the effects of three different population densities on the growth and production of tilapia ( $O$. niloticus) in monoculture.

\section{Materials and Methods}

\section{Experimental ponds}

Six earthen ponds $\left(40 \mathrm{~m}^{2}\right)$ were used for the experiment. All the experimental ponds were arbitrarily numbered as pond no. $1\left(\mathrm{P}_{1}\right)$, pond no. $2\left(\mathrm{P}_{2}\right)$, pond no. $3\left(\mathrm{P}_{3}\right)$, pond no. $4\left(\mathrm{P}_{4}\right)$, pond no. $5\left(\mathrm{P}_{5}\right)$ and pond no. $6\left(\mathrm{P}_{6}\right)$ for the convenience of the research work. Ponds 1 and 5 were under treatment no. I, ponds 2 and 4 were under treatment no. II and ponds 3 and 6 were under treatment no. III.

\section{Fertilization of the ponds}

Fertilization of ponds was done weekly with the application of urea (60 $\left.\mathrm{g} \mathrm{decimal}^{-1}\right)$ and TSP (90 $\mathrm{g}$ decimal $^{-1}$ ). TSP was dissolved in water for 24 hours in a plastic bucket and then applied by spreading over the ponds surface by a mug. Urea was also dissolved in the same plastic bucket before spreading on the water surface of the ponds.

\section{Stocking offish}

Fingerlings of monosex GIFT tilapia ( $O$. niloticus) was stocked in the ponds. In treatmentI fish population density was 80 fish per decimal, 
160 fish per decimal in treatment-II and 320 fish per decimal in treatment-III and fish were released after a week of fertilization. The initial average weight of $O$. niloticus was $0.067 \mathrm{~g}$ and initial average length of $O$. niloticus was $4.48 \mathrm{~cm}$.

\section{Study of water quality parameters}

\section{Methods for study of physical parameters}

Water depth $(\mathrm{m})$ : Depth of water of the experimental ponds was measured with the help of a graduated wooden depth meter.

Transparency $(\mathrm{cm})$ : Water transparency of the experimental ponds was measured by a Secchidisk.

Temperature $\left({ }^{\circ} \mathrm{C}\right)$ : Air and water temperature data were collected from 'Weather Yard' office of the Department of Irrigation and Water Management, BAU, Mymensingh.

\section{Methods for study of chemical parameters}

Dissolved oxygen ( $m g \mathrm{~L}^{-1}$ ): Dissolved oxygen of water was measured by portable digital dissolved oxygen (DO) meter (model: DO5509, Lutron, made in Taiwan).

pH (Hydrogen-ion concentration): $\mathrm{pH}$ was determined by a portable digital $\mathrm{pH}$ meter (Hanna Instruments, Italy, model-H 196107).

Free carbon dioxide ( $m g L^{-1}$ ): For determining free carbon dioxide of water, samples were collected in $250 \mathrm{ml}$ black plastic bottles and titrated with $0.022 \mathrm{~N}$ sodium hydroxide solution using phenolphthalein as indicator .

Total alkalinity ( $m g L^{-1}$ ): To determine total alkalinity, samples were collected in $250 \mathrm{ml}$ black plastic bottles and total alkalinity of water samples was determined by titrimentric method using methyl orange indicator.

Phosphate-phosphours $\left(\mathrm{PO}_{4}-\mathrm{P}\right) \quad\left(\mathrm{mg} \mathrm{L}^{-1}\right)$ : Phosphate-phosphorus $\left(\mathrm{PO}_{4}-\mathrm{P}\right)$ of water samples of the ponds was determined by a digital Phosphate Meter (model HI 93717, Hanna Instruments).

Nitrate-nitrogen $\left(\mathrm{NO}_{3}-\mathrm{N}\right) \quad\left(m g \mathrm{~L}^{-1}\right)$ : Nitratenitrogen $\left(\mathrm{NO}_{3}-\mathrm{N}\right)$ was determined by a digital Nitrate Meter (model HI 93728, Hanna Instruments).

\section{Methods for study of biological parameters}

Collection and preservation of plankton samples: Water samples in a $500 \mathrm{ml}$ bottle were randomly collected for quantitative and qualitative study of phytoplankton and zooplankton of water from different locations of each of the ponds and passed through a plankton net (mesh-size $55 \mu$ ) and finally concentrated to $100 \mathrm{ml}$. Then concentrated samples were preserved in small plastic bottles in 5\% formalin for study under a compound microscope.

Counting of plankton: Counting of both phytoplankton and zooplankton were done with the help of Sedgwick-Rafter Counting Cell (S-R cell).

Calculation of plankton: The plankton population was determined by Sedgwick Rafter counting Cell (S-R Cell) using the following formula (Rahman, 1992).

$\mathrm{N}=\frac{\mathrm{A} \times 1000 \times \mathrm{C}}{\mathrm{V} \times \mathrm{F} \times \mathrm{L}}$

Where,

$\mathrm{N}=$ No. of plankton cells per liter of original water, $\mathrm{A}=$ Total no. of plankton counted, $\mathrm{C}=$ Volume of final concentrate of the sample in $\mathrm{ml}$, $\mathrm{V}=$ Volume of a field $=1 \mathrm{~mm}^{3}, \mathrm{~F}=$ No. of the fields counted, $\mathrm{L}=$ Volume of original water in liter.

The number of phytoplankton and zooplankton were expressed as cells $\mathrm{L}^{-1}$.

\section{Harvesting offish}

At the end of the experiment all the fish of the ponds were harvested by a fish net.

\section{Estimation of survival rate, growth and production offish}

(i) The survival rate was estimated by the following formula:

Survival rate $(\%)=\frac{\text { No.of harvested fishes }}{\text { Initial no.of fishes }} \times 100$

(ii) Specific growth rate (SGR \%) was estimated by the following formula:

$\operatorname{SGR}(\%$ per day $)=\frac{\log _{\mathrm{e}} \mathrm{W}_{2}-\log _{\mathrm{e}} \mathrm{W}_{1}}{\mathrm{~T}_{2}-\mathrm{T}_{1}} \times 100$

Where,

$\mathrm{W}_{1}=$ Initial live body weight $(\mathrm{g})$ at time $\mathrm{T}_{1}, \mathrm{~W}_{2}=$ Final live body weight $(\mathrm{g})$ at time $\mathrm{T}_{2}$

(iii) Calculation of gross fish production (ton ha-1 $\mathrm{yr}^{-1}$ )

$=\frac{\text { Gross weight }(\mathrm{kg}) \text { of fish per decimal per month } \times 250 \times 12}{1000}$

(iv) Calculation of net fish production (ton ha-1 $\mathrm{yr}^{-}$ 1)

$=\frac{\text { Net weight }(\mathrm{kg}) \text { of fish per decimal per month } \times 250 \times 12}{1000}$ 1000

\section{Statistical analysis}

T-test of net fish production of the ponds under three treatments was done by a computer using SPSS package programme. 


\section{Results}

\section{Physico-chemical parameters}

Table 2. Physico-chemical parameters ( $M e a n \pm S D, n=3$ ) of the ponds during the experimental period.
The results of the different physico-chemical parameters of the experimental ponds have been presented in the Table 2.

Parameters
Average water depth $(\mathrm{m})$
Water temperature $\left({ }^{\circ} \mathrm{C}\right)$
Air temperature $\left({ }^{\circ} \mathrm{C}\right)$
Transparency $(\mathrm{cm})$
Dissolved oxygen $\left(\mathrm{mg} \mathrm{L}^{-1}\right)$
Free $\mathrm{CO}_{2}$
$\mathrm{pH}$
$\mathrm{PO}_{4}-\mathrm{P}\left(\mathrm{mg} \mathrm{L}^{-1}\right)$
$\mathrm{NO}_{3}-\mathrm{N}\left(\mathrm{mg} \mathrm{L}^{-1}\right)$
Total alkalinity $\left(\mathrm{mg} \mathrm{L}^{-1}\right)$

Treatment-I
$0.89 \pm 0.019$
$29.64 \pm 0.900$
$29.63 \pm 0.620$
$33.13 \pm 1.870$
$7.64 \pm 0.370$
$4.06 \pm 1.700$
$7.65 \pm 0.140$
$1.62 \pm 0.110$
$3.01 \pm 0.120$
$98.38 \pm 7.530$

\section{Biological parameters}

The results of biological parameters such as phytoplankton density (cells $\mathrm{L}^{-1}$ ) and zooplankton density (cells $\mathrm{L}^{-1}$ ), generic status of phytoplankton and zooplankton and growth and production of fish have been presented in Table 3 .

\section{Phytoplankton (cells $L^{-1}$ )}

The average density of phytoplankton of the ponds under treatment-I was $29.0 \pm 4.66\left(\times 10^{3}\right)$ cells $\mathrm{L}^{-1}$ and that of the ponds under treatment-II

\begin{tabular}{|c|c|}
\hline Treatment-II & Treatment-III \\
\hline $0.94 \pm 0.16$ & $0.89 \pm 0.014$ \\
\hline $29.63 \pm 0.62$ & $29.64 \pm 0.900$ \\
\hline $29.64 \pm 0.90$ & $29.63 \pm 0.620$ \\
\hline $31.6 \pm 1.00$ & $33.38 \pm 1.750$ \\
\hline $7.74 \pm 0.37$ & $7.46 \pm 0.580$ \\
\hline $3.63 \pm 0.99$ & $2.82 \pm 1.870$ \\
\hline $7.62 \pm 0.17$ & $7.75 \pm 0.200$ \\
\hline $1.55 \pm 0.16$ & $1.63 \pm 0.150$ \\
\hline $3.32 \pm 0.11$ & $3.24 \pm 0.270$ \\
\hline $99.19 \pm 9.13$ & $103.56 \pm 11.010$ \\
\hline
\end{tabular}

was $27.29 \pm 2.23\left(\times 10^{3}\right)$ cells $\mathrm{L}^{-1}$ and that of the ponds treatment-III was $26.19 \pm 0.88\left(\times 10^{3}\right)$ cells $\mathrm{L}^{-1}$.

\section{Zooplankton (cells $L^{-1}$ )}

The average density of zooplankton of the ponds under treatment-I was $10.0 \pm 0.93\left(\times 10^{3}\right)$ cells $\mathrm{L}^{-1}$ and that of the ponds under treatment-II was $11.19 \pm 0.70\left(\times 10^{3}\right)$ cells $\mathrm{L}^{-1}$ and that of the ponds under treatment-III was $11.19 \pm 0.37\left(\times 10^{3}\right)$ cells $\mathrm{L}^{-1}$.

Table 3. Generic status of phytoplankton and zooplankton found in the culture pond.

\begin{tabular}{|c|c|c|c|c|}
\hline \multicolumn{5}{|c|}{ Phytoplankton } \\
\hline Chlorophyceae & Cyanophyceae & Bacillariophyceae & Dinophyceae & Euglenophyceae \\
\hline Actinastrum & Anabaena & \multirow{7}{*}{$\begin{array}{l}\text { Asterionella } \\
\text { Cyclotella } \\
\text { Diatoma } \\
\text { Fragilaria } \\
\text { Navicula } \\
\text { Synedra } \\
\text { Tabellaria } \\
\text { Gonatozygon }\end{array}$} & Ceratium & \multirow{8}{*}{$\begin{array}{l}\text { Euglena } \\
\text { Phacus }\end{array}$} \\
\hline Chlorella & Aphamocapsa & & & \\
\hline Closterium & Gomphospaeria & & & \\
\hline Scendesmus & Microsystis & & & \\
\hline Volvox & Oscillatoria & & & \\
\hline Pediastrum & Aphanizomenon & & & \\
\hline $\begin{array}{l}\text { Scenedesmus } \\
\text { Ulothrix }\end{array}$ & & & & \\
\hline \multicolumn{4}{|c|}{ Zooplankton } & \\
\hline \multicolumn{4}{|c|}{ Crustacea } & Rotifera \\
\hline \multicolumn{2}{|c|}{ Cladocera } & \multicolumn{2}{|c|}{ Copepoda } & Asplanchna \\
\hline \multirow{3}{*}{\multicolumn{2}{|c|}{$\begin{array}{c}\text { Daphnia } \\
\text { Diaphanosoma } \\
\text { Moina }\end{array}$}} & \multicolumn{2}{|c|}{ Cyclops } & Brachionus \\
\hline & & \multicolumn{2}{|c|}{ Diaptomus } & Filinia \\
\hline & & Naup & & $\begin{array}{l}\text { Keratella } \\
\text { Polyartha }\end{array}$ \\
\hline
\end{tabular}

\section{Survival rate, growth and production of fish}

Survival rate

The survival rates (\%) of fish were different in different treatments. The survival rates in treatment-I was $91.25 \%$ and in treatment-II was $82.82 \%$ and in treatment-III was $66.23 \%$. The survival rate in treatment-I is significantly higher than those in treatment-II and treatment-III (Table 4).

\section{Specific growth rate (\% per day)}

The specific growth rates (SGR \% per day) of fish in different treatment were different. In treatment-I SGR value recorded was 5.49\% per day and in treatment-II SGR value recorded was 4.95\% per day and in treatment-III SGR value recorded were 4.61 per day. SGR value in treatment-I was higher than those in treatment-II and III (Table 4). 


\section{Production of fishes}

The productions of fish were different in different treatments. The calculated gross productions of fish of the ponds under treatments-I, II and III

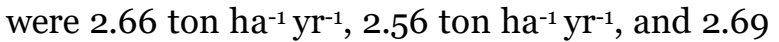
ton $\mathrm{ha}^{-1} \mathrm{yr}^{-1}$, respectively (Table 5). The net productions of fish of the ponds under treatments- I, II, and III were 2.65 ton $\mathrm{ha}^{-1} \mathrm{yr}^{-1}$, 2.55 ton ha- $\mathrm{yr}^{-1}$ and 2.68 ton ha- $\mathrm{yr}^{-1}$, respectively (Table 5). The gross and net productions of treatment-III were slightly higher than those of other two treatments.

Table 4. Total survival rate, growth and production (gross and net) of fishes under treatments I, II, and III.

\begin{tabular}{|c|c|c|c|c|c|c|}
\hline \multirow[t]{2}{*}{ Treatments } & \multirow{2}{*}{$\begin{array}{l}\text { Total } \\
\text { survival } \\
\text { rate (\%) }\end{array}$} & \multirow{2}{*}{$\begin{array}{c}\text { Final total weight } \\
\text { (kgdecimal }^{-1} 4 \\
\text { months }^{-1} \text { ) }\end{array}$} & \multirow{2}{*}{$\begin{array}{c}\text { Initial total } \\
\text { weight } \\
\left(\mathrm{kgdecimal}^{-1}\right)\end{array}$} & \multirow{2}{*}{$\begin{array}{c}\text { Specific } \\
\text { growth rate } \\
\text { (SGR \% per } \\
\text { day) }\end{array}$} & \multicolumn{2}{|c|}{$\begin{array}{c}\text { Production } \\
\left(\text { kgdecimal-1-1year-1) }^{-1} \text {. }\right.\end{array}$} \\
\hline & & & & & Gross & Net \\
\hline I & 91.25 & 3.55 & 0.0054 & 5.49 & 10.65 & 10.62 \\
\hline II & 82.82 & 3.41 & 0.0100 & 4.95 & 10.23 & 10.20 \\
\hline III & 66.23 & 3.59 & 0.0210 & 4.61 & 10.77 & 10.70 \\
\hline
\end{tabular}

Table 5. Gross and net production of fish of the ponds under treatments I, II, and III.

\begin{tabular}{|c|c|c|c|c|c|}
\hline \multirow[t]{3}{*}{ Treatments } & \multicolumn{4}{|c|}{ Production } & \multirow{3}{*}{$\begin{array}{l}{ }^{*} \text { Percent } \\
\text { increase of net } \\
\text { production }\end{array}$} \\
\hline & \multicolumn{2}{|c|}{$\mathrm{Kg}$ decimal $^{-1}$ year-1 $^{-1}$} & \multicolumn{2}{|c|}{ Ton ha-1 year-1 $^{-1}$} & \\
\hline & Gross & Net & Gross & Net & \\
\hline I & 10.65 & 10.62 & 2.66 & 2.65 & $100.00 \%$ \\
\hline II & 10.23 & 10.2 & 2.56 & 2.55 & $96.23 \%$ \\
\hline III & 10.77 & 10.70 & 2.69 & 2.68 & 101.13 \\
\hline
\end{tabular}

*percent increase of net productions of treatment-II and treatment-III, over treatment-I which has been taken for $100 \%$.

\section{Discussion}

The results of the study on various water quality parameters, impacts of fish population densities on the growth and production of tilapia in monoculture system have been discussed below.

\section{Water quality parameters}

\section{Physical parameters}

Physical parameters are very imperative in case of fish production. The results of the different physical parameters during the experimental period were within the acceptable limits for fish culture and these have been discussed below.

Water depth (m): During the experimental period, fortnightly fluctuations of water depth ranged from 0.78 to $0.99 \mathrm{~m}$. Jhingram (1975) stated that a depth of about $2 \mathrm{~m}$ of a pond is suitable from the view point of biological productivity. Rahman (1992) stated that pond should not be shallower than $1 \mathrm{~m}$ and deeper than $5 \mathrm{~m}$ and optimum depth should be $2 \mathrm{~m}$. The mean values of water depth under treatment-I, treatment-II and treatment-III were $0.89 \pm 0.019$ $\mathrm{m}, 0.94 \pm 0.16 \mathrm{~m}$ and $0.89 \pm 0.014 \mathrm{~m}$, respectively. Because of high seepage and high evaporation of water, the water depth of fish ponds was shallower than $1 \mathrm{~m}$, although the supply of water was present from a water supply system of a deep tube-well.
Transparency $(\mathrm{cm})$ : Mean values of water transparency during the experimental period of the ponds under treatment-I, treatment-II and treatment-III were $33.13 \pm 1.87 \mathrm{~cm}, 31.6 \pm 1.00 \mathrm{~cm}$ and $33.38 \pm 1.75 \mathrm{~cm}$, respectively. Rahman (1992) stated that the transparency of productive waterbodies should be $40 \mathrm{~cm}$ or less (turbidity resulting from plankton). Kohinoor (2000) recorded transparency values ranging from 15 to $58 \mathrm{~cm}$. The water transparency values of the ponds under treatment-I, treatment-II and treatment-III were within productive range in the present experiment.

Water temperature $\left({ }^{\circ} \mathrm{C}\right)$ : In the present experiment, the water temperature ranged from 28.5 to $31.5^{\circ} \mathrm{C}$. Paul (1998) recorded temperature ranged from 25 to $35^{\circ} \mathrm{C}$ is suitable for fish culture. In the present experiment water temperature was favorable for fish culture.

Air temperature $\left({ }^{\circ} \mathrm{C}\right)$ : Throughout the experimental period, the air temperature was found to vary from 28.6 to $30.5^{\circ} \mathrm{C}$. Islam and Mendes (1976) reported that the water temperature is always less than the surrounding air temperature and varied with $2^{\circ} \mathrm{C}$. In the present study, the results are nearly similar to those of them. 


\section{Chemical parameters}

All the chemical parameters studied during the experimental period were found within the acceptable range for fish culture, which has been discussed below.

Dissolved oxygen ( $m g L^{-1}$ ): During the experimental period dissolved oxygen content of the ponds were found between 4.90 to $9.0 \mathrm{mg} \mathrm{L}^{-1}$. The mean values of dissolved oxygen content recorded in the present experiment under treatment-I, treatment-II and treatment-III were $7.64 \pm 0.37,7.74 \pm 0.37$, and $7.46 \pm 0.58 \mathrm{mg} \mathrm{L}^{-1}$, respectively. Majumder (2017), Mazid (2009), Sarker (2007) and Chowdhury (2005) found more or less similar results. In the present experiment, the mean dissolved oxygen values were within suitable range.

Free carbon dioxide $\left(m g L^{-1}\right)$ : The fluctuation of free carbon dioxide during the experimental period ranged from 0.0 to $6.00 \mathrm{mg} \mathrm{L}^{-1}$. The mean values of free $\mathrm{CO}_{2}$ content recorded in the present experiment under treatment-I treatmentII and Treatment-III were $4.06 \pm 1.70,3.63 \pm 0.99$, and $2.82 \pm 1.87 \mathrm{mg} \mathrm{L}^{-1}$, respectively. Majumder (2017), Mazid (2009), Sarker (2007) and Chowdhury (2005) found more or less similar results.

$\mathrm{pH}$ (hydrogen ion concentration): The $\mathrm{pH}$ of most natural water ranges from 6.5 to 8.5 . The fluctuation of $\mathrm{pH}$ during the experimental period ranged from 7.30 to 8.10 . The mean values of $\mathrm{pH}$ recorded in the present experiment under treatment-I, treatment-II and treatment-III were $7.65 \pm 0.14, \quad 7.62 \pm 0.17, \quad$ and $7.75 \pm 0.20$, respectively. Swingle (1967) stated that pH 6.5 to 9.0 is suitable for pond fish culture. From the above discussion, we may conclude that $\mathrm{pH}$ values of all the experimental ponds were slightly alkaline which indicate suitable $\mathrm{pH}$ condition for fish culture.

Total alkalinity ( $m g \mathrm{~L}^{-1}$ ): Fortnightly fluctuations of total alkalinity in the experimental ponds ranged from 80 to $124 \mathrm{mg} \mathrm{L}^{-1}$. The mean values of total alkalinity in the present experiment under treatment-I, treatment-II and treatment-III were $98.38 \pm 7.53,99.19 \pm 9.13,103.56 \pm 11.01 \mathrm{mg} \mathrm{L}^{-1}$, respectively. The findings are more or less similar to the results of Majumder (2017), Mazid (2009), Sarker (2007) and Chowdhury (2005).

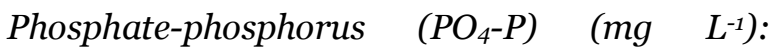
Variations of phosphate-phosphorus $\left(\mathrm{PO}_{4}-\mathrm{P}\right)$ in the experimental ponds ranged from 1.1 to 1.90 $\mathrm{mg} \mathrm{\textrm {L } ^ { - 1 }}$. The average values of $\mathrm{PO}_{4}-\mathrm{P}$ in the present experiment under treatment-I, treatment-II and treatment-III were $1.62 \pm 0.11$, $1.55 \pm 0.16$, and $1.63 \pm 0.15 \mathrm{mg} \mathrm{L}^{-1}$, respectively. Wahab et al. (1995) found the highest concentration of phosphate-phosphorus to vary from 0.09 to $5.20 \mathrm{mg} \mathrm{L}^{-1}$ in nine experimental ponds. In the present experiment, phosphatephosphorus concentrations were within the suitable range for phytoplankton production.

Nitrate-nitrogen $\left(\mathrm{NO}_{3}-\mathrm{N}\right)\left(\mathrm{mg} \mathrm{L}^{-1}\right)$ : Variations of nitrate-nitrogen in the experimental ponds ranged from 2.10 to $3.90 \mathrm{mg} \mathrm{L}^{-1}$. The mean values of $\mathrm{NO}_{3}-\mathrm{N}$ in the present experiment under treatment-I, treatment-II and treatment-III were $3.01 \pm 0.12,3.32 \pm 0.11$, and $3.24 \pm 0.27 \mathrm{mg} \mathrm{L}^{-1}$, respectively. Das (2002) recorded the range of nitrate-nitrogen values from 1.60 to $3.22 \mathrm{mg} \mathrm{L}^{-1}$, which is more or less similar to the values obtained in the present experiment.

\section{Biological parameters}

Phytoplankton: The average density of phytoplankton of the ponds under treatment-I was $29.0 \pm 4.66\left(\times 10^{3}\right)$ cells $\mathrm{L}^{-1}$ and that of the ponds under treatment-II was $27.29 \pm 2.23\left(\times 10^{3}\right)$ cells $\mathrm{L}^{-1}$ and that of the ponds under treatmentIII was $26.19 \pm 0.88\left(\times 10^{3}\right)$ cells L-1. Kabir (2003), Chowdhury (2005) and Sarker (2007) found more or less similar results. A total number of 25 genera of phytoplankton belonging to 5 different groups of Bacillariphyceae, Chlorophyceae, Cyanophyceae, Dinophyceae and Euglenophyceae were found in the experimental ponds.

Zooplankton: During the present experiment the mean values of zooplankton in the experimental ponds under treatment-I, treatment-II and treatment-III were $10.0 \pm 0.93\left(\times 10^{3}\right), 11.19 \pm 0.70$ $\left(\times 10^{3}\right)$ and $11.19 \pm 0.37\left(\times 10^{3}\right)$ cells $\mathrm{L}^{-1}$, respectively. Ten genera of zooplankton belonging to the groups of crustacea (Cladocera and Copepoda) and Rotifer were found in the experimental ponds. Majumder (2017), Mazid (2009), Sarker (2007) and Chowdhury (2005) found more or less similar results in different experiments in fish culture ponds.

\section{Survival rate, growth and production of fish}

Survival rate (\%): The survival rates in treatment-I was $91.25 \%$, in treatment-II was $82.82 \%$ and in treatment-III was $66.23 \%$. Sultana (2015) obtained survival rates 93.75\%, 91.88\%, 86.88\% under treatment-I, treatment-II, and under treatment-III in polyculture of tilapia, rui, catla and mrigal. In the present experiment survival rate was comparatively lower in treatment-III (66.23\%) than in treatment-II $(82.82 \%)$ and in treatment-I (91.25\%).

Specific growth rate (SGR \% per day): The specific growth rate in treatment-I, II and III were $5.49 \%, 4.95 \%$ and $4.61 \%$, respectively. There were considerable differences among the 
different treatments. SGR progressively decreased with the increase in stocking density. The significant highest specific growth rate (5.49\%) was observed in treatment-I. The lowest specific growth rate (4.61\%) was observed in treatment-III. Begum (2009) and Rahim (2010) who recorded specific growth rate ranged 2.36 to $2.65 \%, 3.65$ to $3.79 \%$ and 3.09 to $3.34 \%$. They obtained the highest values of specific growth rate at lowest stocking densities.

Production of fish: In the present experiment, calculated gross and net productions of tilapia of the ponds under treatment-I (fish population density 80 fish per decimal) were 2.66 ton $\mathrm{ha}^{-1} \mathrm{yr}^{-}$ ${ }^{1}$ and 2.65 ton $\mathrm{ha}^{-1} \mathrm{yr}^{-1}$ and those of the ponds under treatment-II (fish population density 160 fish per decimal) were 2.56 ton $\mathrm{ha}^{-1} \mathrm{yr}^{-1}$ and 2.55 ton $\mathrm{ha}^{-1} \mathrm{yr}^{-1}$ and those of the ponds under treatment-III (fish population density 320 fish per decimal) were 2.69 ton $\mathrm{ha}^{-1} \mathrm{yr}^{-1}$ and 2.68 ton $\mathrm{ha}^{-1} \mathrm{yr}^{-1}$, respectively. The highest production of fish was found from treatment-III (320 fish per decimal) because of high population density but mean weight gain was higher in treatment-I because of lower population density (8o fish per decimal). The present results supports the findings of Begum (2009) and Rahim (2010) who achieved the higher production from higher stocking densities compared to that achieved with the lower densities. Sultana (2015) obtained gross and net production 8.87 and 7.33 ton ha-1 $\mathrm{yr}^{-1} ; 7.12$ and 5.58 ton $\mathrm{ha}^{-1} \mathrm{yr}^{-1} ; 4.69$ and 3.16 ton $\mathrm{ha}^{-1} \mathrm{yr}^{-1}$ under treatment-I, treatment-II, and treatment-III, respectively, which are more than those of the present experiment.

From the above discussion, it is apparent that the population density of 80 fish per decimal is the best for monoculture of monosex GIFT tilapia $(O$. niloticus). In treatment-III benefit was negative i.e. there was loss (23\%) because of higher fish population density (320 fish per decimal). So excessive higher fish population density do not give profit rather there may be loss.

\section{References}

Ahmed, M. 1956. Transplantation of food fish to Pakistan. Pakistan J. Agril. Sci. 8(4): 167170.

Ballarin, J.D. and Haller, R.D. 1982. The intensive culture of Tilapia in tanks, raceways, and cages. In: J.f. Munir \& R.J. Roberts (eds). Recent advances in Aquaculture. Wes view press. Boulder, Colorado, USA. pp. 265-355.

Begum, M. 2009. Effects of stocking density on growth and production performance of mono-sex Tilapia (Oreochromis niloticus) in ponds. MS Thesis, Department of
Aquaculture, Bangladesh Agricultural University, Mymensingh, Bangladesh. 66p.

Chowdhury, M.M.R. 2005. Use of duckweed (Lemna minor) as supplementary feed in monoculture of tilapia (Oreochromis niloticus). MS Thesis, Department of Fisheries Management, Bangladesh Agricultural University, Mymensingh. 79p.

Das, B.C. 2002. Studies on the effects of stocking density on growth, survival and yield of Amblypharyngodon mola and performance of Rohtecotio in combination with Barbodes gonionotus and with Cyprinus carpio in rice fields. MS Thesis, Department of Aquaculture, Bangladesh Agricultural University, Mymensingh, Bangladesh. pp. 43-45.

DoF. 2009. National Fish Week, 30 July to 5 August, 2009. Fish Culture in Flood affected Land. Department of Fisheries, Ramna, Dhaka. 85p.

Islam, A.K.M.N. and Mendes, J.K. 1976. Limnological studies of a jheel in Sher-EBangla Nagar. Dhaka Univ. Stud. 24(2): 6371.

Jhingram, V.G. 1975. Aquaculture lecture, Summer Int. Intensive fresh water Fish culture, Cuttack, Organized by Centre, Inland Fish. Res. Inst., Barackpore (ICAR), India. p. 12.

Kabir, A.N.M.A. 2003. Use of Duckweed (Lemna minor) as feed for fishes in polyculture. MS Thesis, Department of Fisheries Management, Bangladesh Agricultural University, Mymensingh, Bangladesh. 55p.

Kohinoor, A.H.M. 2000. Development of culture technology of three small indigenous fish mola (Amblypharyngodon mola), punti (Punti ussophore) and chela (Chela cachius) with notes on some aspects of their biology. $\mathrm{PhD}$ Thesis, Department of Fisheries Management, Bangladesh Agricultural University, Mymensingh, Bangladesh. 75p.

Maclean, J.L. 1984. Tilapia - the aquatic chicken. International Center for Living Aquatic resources Management (ICLARM) News Letter. 7(1): 17.

Majumder, T.H. 2017. Effects of population density on growth and production of tilapia in monoculture. MS Thesis, Department of Fisheries Management, Bangladesh Agricultural University, Mymensingh, Bangladesh. 42p.

Mazid, M.A. 2009. Impacts of fish population density in the growth and production of carps in polyculture system. MS Thesis, Department of Fisheries Management, Bangladesh Agricultural University, Mymensingh, Bangladesh. 69p. 
Paul, S. 1998. Comparison between carp polyclture system with silver carp, (Hypophthalmichthys molitrix) and with small indigenous fish mola, (Amblypharyngodon mola). MS Thesis, Department of Fisheries Management, Bangladesh Agricultural University, Mymensingh. 85p.

Pullin, R.S.V. 1985. Tilapias: "Every mansfish". Biologist. 32(2): 84-88.

Rahim, A. 2010. Effects of stocking density on growth and production performance of monosex Tilapia (Oreochromis niloticus) in ponds. MS Thesis, Department of Aquaculture, Bangladesh Agricultural University, Mymensingh, Bangladesh. 71p.

Rahman, M.M. 1995. An economic study of pond fish culture in some selected area of Mymensingh District. MSc Thesis, Department of Agricultural Economics, Bangladesh Agricultural University, Mymensingh, Bangladesh. pp. 49-51.

Rahman, M.S. 1992. Water Quality Management in Aquaculture. BRAC Prokashana, Dhaka1212. $84 \mathrm{p}$.
Sanches, L.E.F. and Hayashi, C. 1999. Stocking density effect on Nile Tilapia (O. niloticus) fry performance during sex reversal. Acta Seientiarum. 21: 619-625.

Sarker, M.K.H. 2007. Impacts of duckweed powder as an ingredient of feed on production of Tilapia (Oreochromis niloticus). MS Thesis, Department of Fisheries Management, Bangladesh Agricultural University, Mymensingh. 87p.

Sultana, S. 2015. Effects of different amounts of supplementary feed on population of fishes in polyculture. MS thesis, Department of Fisheries Management. Bangladesh Agricultural University, Mymensingh. 53p.

Swingle, H.S. 1967. Standardizations of chemical analyses for water and pond muds. FAO Fish Rep. 4: 397-421.

Wahab, M.A., Ahmed, Z.F., Islam, M.A. and Rahmatullah, S.M. 1995. Effect of introduction of common carp, Cyprinus carpio (L), on the pond ecology and growth of fish in polyculture. Aqua. Res. 26: 619628. 